\title{
SUSTAINABLE MARINE ECOTOURISM MANAGEMENT: A CASE OF MARINE RESOURCE CONSERVATION BASED ON LOCAL WISDOM OF BAJO MOLA COMMUNITY IN WAKATOBI NATIONAL PARK
}

\author{
MARLINA \\ Universitas Negeri Malang, Faculty of Social Science, Geography Department, Indonesia, e-mail: marlinamalaia@gmail.com \\ SUMARMI* \\ Universitas Negeri Malang, Faculty of Social Science, Geography Department, Indonesia, e-mail: sumarmi.fis@um.ac.id \\ I Komang ASTINA \\ Universitas Negeri Malang, Faculty of Social Science, Geography Department, Indonesia, e-mail: komang.astina.fis@um.ac.id
}

\begin{abstract}
Citation: Marlina, Sumarmi, Astina, I.K. (2020). SUSTAINABLE MARINE ECOTOURISM MANAGEMENT: A CASE OF MARINE RESOURCE CONSERVATION BASED ON LOCAL WISDOM OF BAJO MOLA COMMUNITY IN WAKATOBI NATIONAL PARK. GeoJournal of Tourism and Geosites, 32(4), 1317-1323. https://doi.org/10.30892/gtg.32419-575
\end{abstract}

\begin{abstract}
Wakatobi National Park has much tourism potential, so management and protection are needed to maintain its sustainabilit. The purpose of this study was to review local wisdom of Bajo Mola community to manage sustainable marine ecotourism in the Wakatobi National Park Area. This study used descriptive qualitative method. The data was collected through observation, in-depth interviews, documentation and literature review then analyzed using the triangulation models. The results of this study found that the conservative tradition which still survives and applies in Bajo community was duata sangal, parika and pamali. That local wisdom must be maintained for the sustainability of marine ecotourism in the Wakatobi National Park area. For bajo people, living on the sea means not only as income sources but also a s tradition.
\end{abstract}

Key words: Local Wisdom, Bajo Mola, sustainable tourism, Wakatobi National Park

$* \quad * \quad * \quad * \quad * \quad *$

\section{INTRODUCTION}

Human life cannot be separated from its environment. It is because of humans and the environment always has an emotional or functional relationship that can affect both components. The relationship between humans and their environment has formed a system of local knowledge to manage the environment and their natural resources (Mutia et al., 2019). Human action, either passive or active, can be a determining factor for the continuity and sustainability of natural resources that have been provided by the gods. One action could affect the increase or decrease of the environmental quality and directly impact on human life itself. When the environment is not maintained, it can give a negative impact on humans, but if maintained, it can provide welfare for humans (Suprayogo, 2013).

The role of local wisdom is needed to manage the environment as an act of sustainability. Local wisdom is a form of environmental wisdom on social life in a place or region (Wahyuni and Hasanah, 2016), which is always related to humans and the environment. Local wisdom is mostly influenced by traditional values such as how a social group implements the principles of conservation, management and exploitation of natural resources (Masita, 2012). Those contain lessons to maintain and utilize natural resources in a sustainable manner. There are many examples of the local wisdom in the community about managing coastal and marine resources, such as the local wisdom of Madurese fishermen to utilize fisheries products called "Onjem" which is made of ropes, coconut leaf stems, and buoys, and mounted using weights to the deep sea. Therefore, it attracts fish to gather even during the dry and starving seasons (Sumarmi et al., 2019).

Along with the rapid modernization, concern for the conservation of natural resources continued to decline. It is caused by high exploitation and inappropriate use to meet human needs. Environmental issues in the 21st century are triggered by the indiscretion of development, the application of science and technology and the lack of environmental knowledge that causes negative impacts in all aspects of life (Sumarmi, et al. 2019). As an example was the rise of various cases in the Wakatobi National Park area such as destructive, illegal fishing, sand mining, lack of management synergy (visitors and the fishing businesses), as well as ineffective management of tourism, excessive exploitation of resources and other technical problems such as government policies in conservation have not been resolved to this day (Dirhamsyah, 2016; Sopari et al., 2014; Khasanah, 2019; Lewin et al., 2010)

Tourism is also affected by human activity even though it contributes to the state revenues. It is caused by the lack of communication and coordination between related parties that involved publishing information about the ecotourism development, also the lack of understanding of ecotourism by the public, as well as the existence of internal political dynamics (Nasrun, 2016). Piartrini (2018) revealed that tourism involves the interaction of individuals from different regions and cultures from the local community then creates a social and economic relationship.

Local community involvement is needed in creating local wisdom to realize sustainable tourism development. Albrecht (2010) stated that community involvement in tourism planning determined by the community's perception of the tourism development plans itself, including how the potential for economic, social, and environmental impacts on the community livings. Sustainable tourism is a tourism approach that emphasizes the importance of the host community and also aims to optimize the economic benefits of tourism for the host community. Management of the park with the Bajo culture is expected to be effective to maintain the Wakatobi National Park (Elliott et al., 2010).

\section{Literature Review \& Theoretical Framework}

Local wisdom is human intelligence in utilizing nature. Local wisdom is similar with human behavior related to God, natural signs, agricultural environment, home construction, education, marriage and birth ceremonies, food, life cycle, health and disaster management (Wagiran, 2012). Sartini (2014) stated that local wisdom functions as (1) the conservation and preservation of natural resources, (2) the development of natural resources, (3) the cultural and scientific resources, and (4) the advice, beliefs, literature, and restrictions in the community.

\footnotetext{
* Corresponding author
} 
It is necessary to know the function of local wisdom so that sustainable marine ecotourism management could run as expected for the area that makes tourism as the main asset. One region that makes tourism as the primary income is Wakatobi Regency. The improvement of Wakatobi tourism was made through community-based management strategies. Maritime tourism is the main sector developed by the Wakatobi regional government. Tourism is developed through community-based management that integrated into the concept of ecotourism. The principle of management is to improve the welfare of the community independently and maintain environmental sustainability. This management system involves the government, the foreign private sector and the community. To realize community-based tourism management in Wakatobi, the Government and National Park Offices then formed a Tourism Awareness Group (Pokdarwis) (Dilwan and Astina, 2019).

As an area with a lot of natural resources potential, the conservation of Wakatobi National Park urgently needed to be done. Wakatobi is one of the national parks and biosphere reserves (UNESCO, 2012) in Indonesia. It showed that Wakatobi has strategic role in the Eastern of Indonesia. Along with the opinion of Turak (2003) that stated Wakatobi as a biodiversity hotspot functions as a larval supplier for fish resources (Sumber Daya Ikan) and marine biodiversity resources (Keanekaragaaman Hayati Laut). The population of Wakatobi in 2018 reached 94,985 (BPS, 2019) and fishing was the main source (94\%) of the community livelihood. The great potential of marine and fisheries is seen from the large number of people who depended on this sector.

Living around the Wakatobi National Park area gave blessings to the Bajo Mola community because of the rich sources of marine products. The life of Bajo people who live in coastal areas and survive with marine resources has shaped their behavior to depend on marine products. It was proved by almost $98 \%$ of the community working as fishermen to such as tuna, coral, squid and others. Therefore, the role of fisherman gave a diverse economic impact on the community.

With a fairly large number of people in the Bajo Mola community currently at 7,035 people (BPS, 2019) can have an impact on resource exploitation. Bajo people viewed that sustainability could be realized with belief in Gods and have encouraged their self-conscious to manage existing resources. Another study analyzed that the Bajo community has a good arrangement to capture the location based on group behavior (Bahtiar, 2012). The continuation of the Bajo community in preserving marine resources was supported by regulating fishing time and using a traditional boat called "Leppa or Sopek" (Artanto, 2017).

Integrating the management of the Wakatobi National Park area with the local wisdom of the community can improve sustainable marine ecotourism. It was supported by how the Bajo people interpret the meaning of a sea. For Bajo culture, the sea is not seen only as a place to live and income sources, but it is also a place for the spirits of their ancestors. Bajo people have a unique maritime culture system, which if traced, studied and developed can be adapted in the management of coastal and marine resources (Wani and Ariana, 2018; Bennet, 2019).

If Wakatobi tourism management runs well, tourism can be beneficial for the community, not only for the current time but also in the future. The Wakatobi National Park management plan for the next ten years $(2018$ - 2027) is directed to optimize the potential of the natural environmental services through the development of destinations while maintaining the integrity and conservation of existing resources as the primary assets aligned with the vision of Wakatobi National Park, which is "Wakatobi National Park as The World's Best Maritime Ecotourism Destination" (RPJP TNW, 2018-2027). Based on these considerations, the role of local wisdom is very much needed.

\section{METHODOLOGY}

\section{Population and Participants}

Bajo Mola residence in Wakatobi Regency is administratively divided into five villages, namely Bakti fishing village, South Mola village, Mola Samaturu village, North Mola village and Mola Bahari village. The five villages are better known as Mola Village or Bajo Village located in the south of Wangi-Wangi sub-district area. The geographical position of Mola Village located on the coast with an area of $\pm 8.3 \mathrm{Km}^{2}$ and the boundaries are followed; (1) the north is bordered by the sea, (2) the east is bordered by Mandati III village, (3) the south is bordered by the sea and (4) the west is bordered by the Strait of Oto Uwwe Island. The research location can be seen in Figure 1 below.

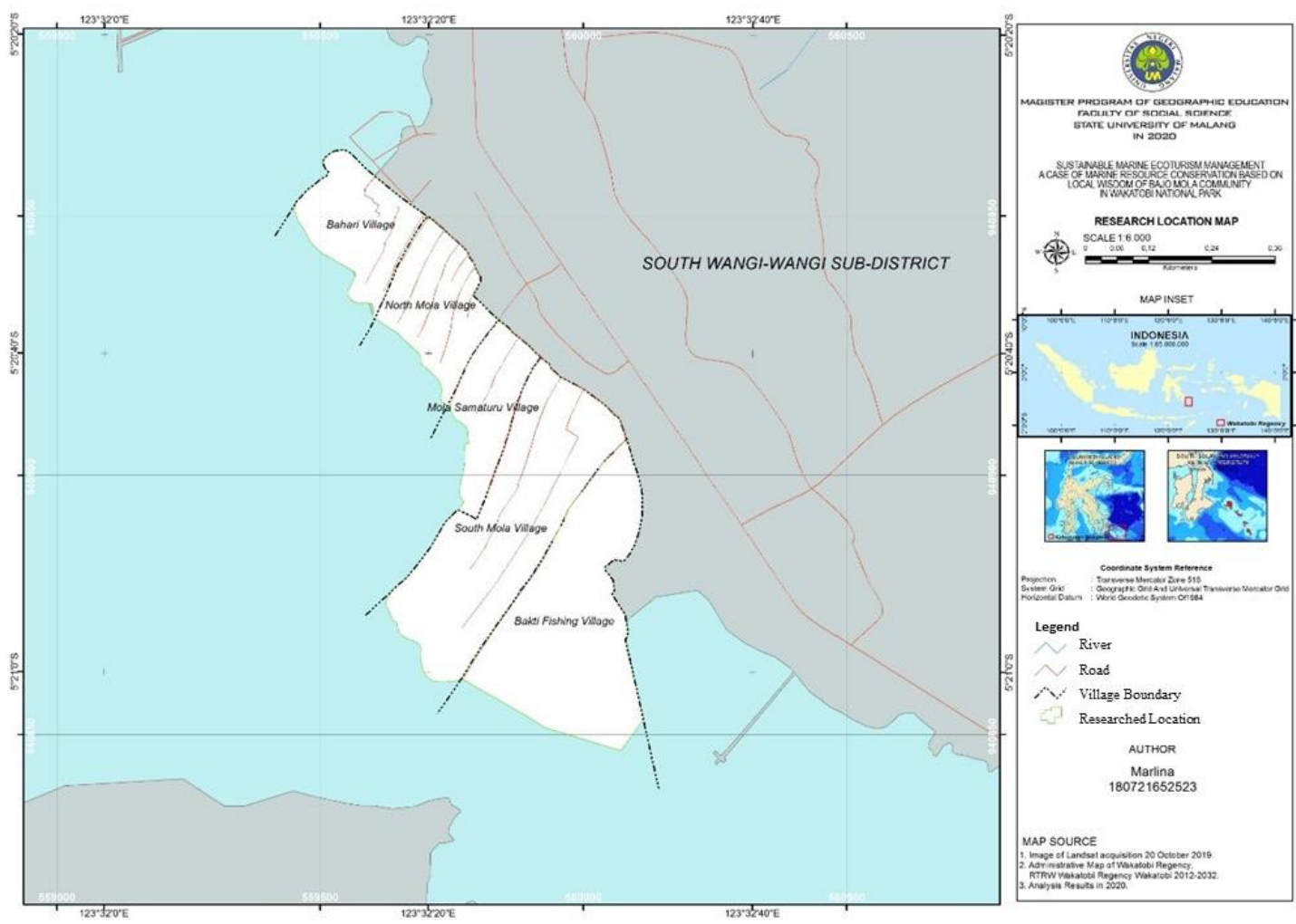

Figure 1. Bajo Mola Village, Wakatobi Regency (Source: Rencana Pengelolaan Jangka Panjang Balai TNW, 2018) 
Physically, Bajo Mola Village is a village formed above the sea and located on the coast of Mandati. As a result of reclamati on, the Mola village has an evenly distributed topography in the entire region of around 1-2 meters above sea level, which is relatively flat (between 0\% -5\%). The climatology conditions of Mola Village are divided into two seasons: the dry season (also called the east season) which runs between April - August and the rainy season (called the west season) which lasts from September to April with a daily temperature of $19^{\circ}-34^{\circ} \mathrm{C}$ (RPJP, 2020). The geographical condition of the Mola village is influenced by the Flores Sea and the Banda Sea. In the west season, the waves and streams can be quite large, while in the east season are relatively calm.

As the bio-ecological status, the Mola seaside consists of several essential ecosystems, like seagrass and coral reefs in which live various types of marine creatures such as baronang fishes, crabs, sea cucumbers, shellfishes and other small fishes. Recent data showed the rapid growth of Bajo people in Mola village so that it is proposed to become a new sub-district of Wangi-Wangi island. Bajo Mola people have experienced many changes in their lifestyles, jobs, and rituals in daily life. Though the Bajo community is divided into five villages, their characteristics as Bajo people remain the same in every village. This division is only an attempt by the government to facilitate the administration process. The condition of habitation of Bajo people can be seen in Figure 2.

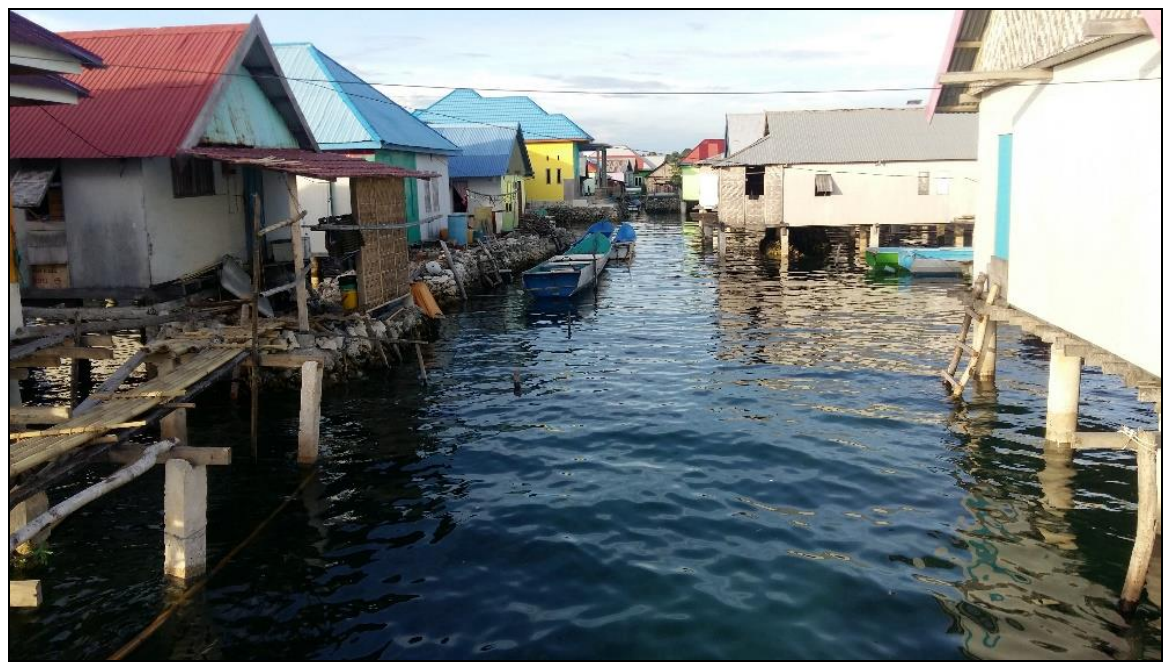

Figures 2. Bajo Community Habitation above the Sea

\section{Data Collection Methods}

This study used descriptive qualitative method. The data collected through observation, in-depth interviews, documentation and literature review. This study was conducted in five Bajo Mola villages in Wakatobi Regency, Indonesia. The data were obtained from key informants, namely Bajo traditional leaders and supporting informants from the Wakatobi National Park office, local government, and Bajo Mola community leaders. The key informants were traditional leaders called Mbo 'Daseng / Sandro from Nelayan Bakti Village and Mr Hakir from the north Mola, then supporting informants were Mr Salahudin as the head of the north Mola village and Mr Hartono as chairman of the Padakuangsama community in the north Mola village. There are also several community leaders in the five Bajo Mola villages as the informants.

\section{Data Analysis}

The data analysis used the triangulation model to study the local wisdom of Bajo Mola community for the sustainable marine ecotourism management around Wakatobi National Park. Moleong (2016) stated that triangulation is a data validity technique that uses something other than the data to check or partially compare the data. Researchers first conducted a literature study from various sources and then checked the data by conducting observation and in-depth interviews with traditional leaders, the government, the community and with the officials of Wakatobi National Park. Interviews conducted with traditional leaders, local government and communities related to the meaning of the sea for the Bajo people, the local wisdom of Bajo used to protect the sea, also on how the Bajo people assess the existence of Wakatobi National Park. Furthermore, interviews were also conducted with Wakatobi National Park officials related to community involvement, especially the Bajo Mola community to manage the Wakatobi National Park. The data were obtained from the informants later.

\section{RESULTS DISCUSSIONS}

\section{The Local Wisdom of Bajo Community}

For the Bajo people, living on the sea gives a special meaning as it feeds and provides for the house. The meaning directly formed a unique culture. Even the modernization is very fast, but it was not necessarily abandoned the culture of ancestors. Bajo Mola people still highly respect and support the culture and customs of their ancestors, proved by how local wisdom affect every marriage procession and the procession before going to the sea. The type of conservative tradition that still survives and applies in Bajo society can be explained as follows:

\section{Duata Sangal}

Duata sangal is an activity to put betel nut off the sea. It consists of two words, "Duata" means request and "Sangal" means a dish for the ancestors of Bajo people (also known as "the sea people). The ritual is carried out if they get obstacles or difficulties during fishing in the sea. The duata ritual is generally the peak ritual of the Bajo people, which is taken when the traditional healing rituals, such as kaka, tuli, kutta, or kadilaok kadara did not find results. Therefore, a wealthy family that was classified will continue to the last stage, the duata ritual. Implementation of the ritual requires a high cost because it was held for about three days. Mbo 'Daseng, a special sanro who lead this ritual, stated that the preparation of ritual equipment, materials for offerings, and any preparation before the ritual begin, as well as the dancers who would be present at the ritual, making this ritual more expensive.

This ritual also presents a variety of arts such as music which is played using drums and gongs. There are also dance arts that involved sick people or one of the duata descent (the Bajo whose parents have performed this ritual) who can dance and feel the spirits enter his body. Furthermore, there is the performing art played by the sanro, who leads the ritual. 
The duata ritual also performed before going to the sea called the sangal duata. The process of this ritual looks simpler than other rituals such as the duata ritual for treatment. The ritual is carried out over the sea by folding 4 pieces of betels (luppiseba) cros swise that has been filled with stuff such as areca nut, lime, gambier and tobacco with the position of betel leaves should face upward. The folds of the betel leaf (also called sangal) are then sent down to the sea after certain prayers have been read. Then it is observed how the movement of the sangal, overlapped or separated, following the sea wave. The contain of betel can be seen in Figure 3.

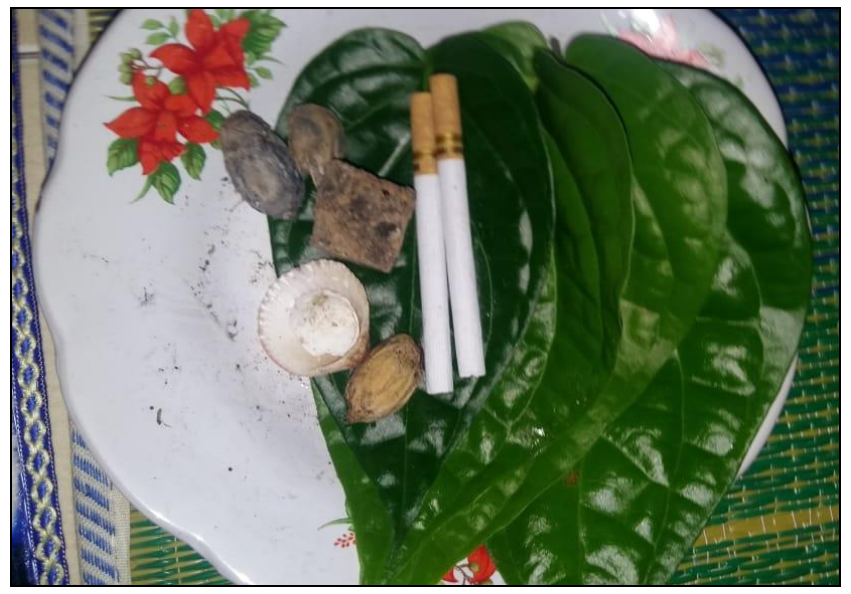

Figure 3. The contain of Sangal

Bajo people believe that the movement was not caused by the sea wave, but sangal is an indication from the Bajo ancestors before going out to the sea. It provides clues about how much luck will be gained that day. Mr HK explained that if the movements move away then gathers again, and then the fortune that will be obtained will be very large, such as the catch result will be much. Meanwhile, if the movement is silent and slow gathering, it shows that the luck gained is little or nothing. Sangal is used as a greeting for fishing. Another meaning is as a request from the Bajo to God for all the catch that has been given.

The four betel crosses in the sangal ritual means the four characteristics of human direction, namely the right, left, front and back sides. It also means that the nature of human physical perfection consisting of four senses, namely the eyes, e ars, nose and mouth, which if the four senses owned then the human is considered perfect. The ritual has a condition interpreted as a way for the Bajo people to be grateful for the natural resources that God has created to be managed wisely as a form of obedience. For the Bajo, the sea is a resource that can be owned by permission from God and must be maintained from damage.

\section{Parika}

The relationship between humans and their environment can indirectly affect the knowledge system and the models of human life. The existence of the knowledge system as a result of the adaptation process to nature has formed the local wisdom. Local wisd om is knowledge or way of life that shows as the activities of local communities such as customs, religion, science, economics, communication, and art, which functions to answer various problems in maintaining, repairing, developing elements of their needs by paying attention to ecosystems, and human resources (Marfa'i, 2012; Sumarmi, 2019; Sumarmi, 2020). For the Bajo Mola community, the knowledge system of the sea is a gift from the Gods that have had it from their ancestors.

The knowledge had by the Bajo to keep marine resources can be seen in their parika (a fisherman leader). Parika is the chairperson, leader, and coordinator who has the authority and responsibility to lead the marine activities under the authority of a punggawa (the owner). The knowledge is believed by Bajo fishermen to be able to regulate and direct the activities of fishing to get much catch. Parika has a big task so that to be a parika must meet certain requirements. The requirements are: (1) having extensive knowledge and enough experience to lead the sea activities, (2) having the leadership, (3) responsible and (4) trustworthy.

Bajo people think that parika is a smart person who has had many catches. According to Mr HK, the ability of parika to manage marine resources can be seen from his knowledge to arrange the right time to go to the sea, to know the nature of fish, the time of fish to lay eggs and hatches, the fishing spots, and others. The knowledge about the sea owned by Bajo fishermen is no doubt because for the life of Bajo people are very close to the sea. Parika knew the right time to go to sea in a certain area every year. Parika managed all activities at a certain time. Within a year, parika could be managed six months to fishing on the reef and the rest six months on the deep sea. Fishing on the reef started in October-April (the west season). The reef fish caught are sunu and grouper fish. Fishing for sunu fish was best done in OctoberDecember, while for grouper fish was in January - April. Then from April to October (the east season) was the right time to fishing the tuna.

The parika knowledge of fishing on the coral was based on the calculation of the moon cycle. One cycle takes 29.5 days so that this period is the right time for fish to lay eggs and hatch. The reef fish such as grouper and sunu fish spawn from the 15 th day to the 26 th. On the night of the 27 th day is a time for fish to lay eggs. The method used by the fish is to jump to the surface of the sea and spray the eggs. During this time, fish eggs will scatter on coral reefs until they hatch and become small fishes. Then, on the 28th day to the 29th day is the right day to catch the reef fish, because at that time the fish enter the hunger phase after laying eggs, so it has a high possibility for fishers to get much catch. The process of breeding such the reef fish lasts for up to 6 months. In the breeding season, parika gives fishers time to catch other marine animals such as octopus, shellfish and others.

Fishing activities are mostly influenced by weather and climate conditions. Parika knows certain times, such as during the transition season (around April-May) can affect the fish activity. Some reef fish prefer strong waves compared to other types of fish that prefer calm waves. Usually, tuna will find food during that time or when they are carried by the waves followed by a crowd of dolphins is a sign that they are rising to the surface. At the same time, seabirds will come to look for food. Fishers use this condition as a guide to fishing in that zone. Fishermen observe dolphin activity on the surface while throwing bait, but sometimes the bait is eaten by seabirds. If the bait gets maximum results, the tuna caught can even reach tens of kilograms. According to $\mathrm{Mr} \mathrm{HK}$, the tuna fishing season is often constrained by the strong waves. At that time, the Bajo people asked for guidance from their ancestors by putting betel nuts in the sea (duata sangal). In certain conditions, Bajo people even give their foods, such as rice or others. 
The decision made by parika to catch fish was based on the consideration that fish must be given space to lay eggs and hatch and to limit fishing activity on a certain time agreed by traditional leaders and community leaders. This method intended so that fish can lay eggs and hatch without interference from humans. Parika taught how to manage and use wisely the coastal and marine resources.

\section{Pamali}

Pamali means a prohibition, which is a restricted area to catch fish that has been determined by the traditional leader. Fishing activities in these zones acted as a violation and were banned under regulations. Pamali for Bajo people is the rules that mu st be obeyed by all communities, especially for fishers who were fishing at sea.

Pamali locations known by Bajo Mola are around the Kapota reef. There are 3 locations of pamali namely "maduangalo" (means the front of the house), "mabulisapa" (means the back of the house) and torosapa (a large rock shaped like a fisher on a boat). Maduangalo is located in the northwest of the Kapota reef while mabulisapa in the southeastern part of the Kapota reef until it borders the tip of the Kaledupa reef. Pamali location of maduangalo and mabulisapa based on the zone map is the Wakatobi National Park tourism zones. Then the torosapa at the southern end of Wangi-Wangi Island or in the eastern part of Kompoone Island is the marine protection zone of Wakatobi National Park area. The zone map can be seen in Figure 4.
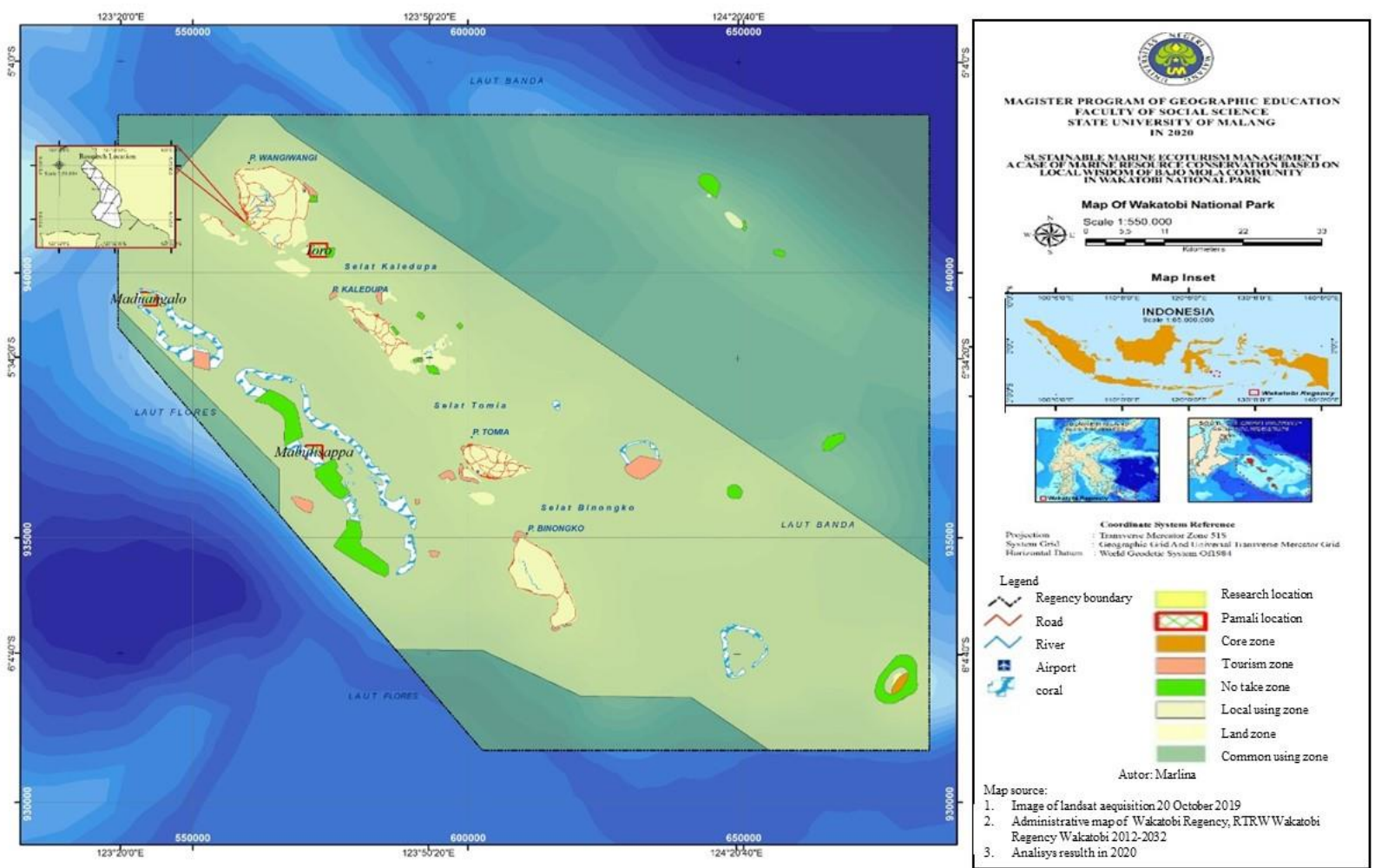

Figure 4. The Zone Map of Wakatobi National Park (Source: Rencana Pengelolaan Jangka Panjang Balai TNW, 2018)

Activities are forbidden to do in pamali locations such as cursing, shouting, immoral and littering. Although the Bajo people know that the pamali area is a zone that has a lot of fish, they do not dare to do activities that are prohibited in that zone. They considered shouting as a violation as well as booming, using potassium or anesthesia. The zone consists of the core zone, protective zone, rehabilitation zone, utilization zone, and traditional utilization zone.

For Bajo people, the pamali is a very sacred area and is feared because there lives a guardian to protect the place. Bajo people believe that pamali is a gathering place for fish, just like humans who gather and then return to their homes. Pamali means that the natural potential and resources are a gift from God, but humans are given knowledge and moral to limit them and use wisely so that the next generation can enjoy it.

\section{Integration of Wakatobi National Park Management with Bajo Local Wisdom}

Humans have used natural resources in various ways, especially in the tourism area. In the last few decades, tourism has developed into a sustainable tourism activity by making nature and culture as the main objects (Firdaus et al., 2019). Integrating the management of tourism areas with culture is an act of mutual support and can add economic benefits. Tourism is one of the most effective solutions to overcome rural poverty. The economic benefits received from the diversity of occupancies are reasons for people to preserve the environment through the tourism management of community group (Purnomo et al., 2020; Kurniawati et al., 2020; Sumarmi, 2020). Even the Wakatobi National Park planned as the leading destination for marine ecotourism in the world, but it can decrease if it is not managed optimally. It occurred because human needs are increased but not followed by conservation awareness. For this reason, the integration of sustainable tourism management with community involvement is needed.

Wakatobi National Park has a lot of potential so that the development was increased. The government has launched a program of 10 Indonesian Tourism Leading Destinations for 2015-2019 (Dilwan et al., 2019). Wakatobi Islands and the surrounding within an area of \pm 1,390,000 Ha are designated as National Parks based on Minister of Forestry's Decree No. 393 / Kpts-VI / 1996, on 30 July 1996 (MENHUT, 1996), and has been settled based on Minister of Forestry Decree No. 7651 / Kpts-II / 2002 , 19 August 2002 (MENHUT, 2002). This area consists of four large islands, namely Wangi-Wangi Island, Kaledupa Island, Tomia Island and Binongko Island and then divided into five districts which are included in the Administrative District area of Wakatobi, province of Southeast Sulawesi. Wakatobi National Park (TNW) is managed by a zoning system, which is determined based on Decree of the General Directory of Forest Protection and Nature Conservation No. 198 / Kpts / DJ-VI / 1997 on 31 December 1997 (MENHUT, 1997). 
The long-term management plans and strategies for Wakatobi National Park in 2018-2027 were based on the vision, mission, goals, the SWOT analysis results, strategic issues and the scope of management. The scope of management was focused on three aspects, namely regional management, natural resource management and environmental services also institutional management. Strategies to be used in the long-term management plan for 2018-2027 include: (1) adding socialization area and management area to stakeholders in the park; (2) doing collaborative management, community empowerment, and security with various parties including the law enforcement officials, regional governments, communities and indigenous peoples in the park; (3) improving the management of natural resources and their ecosystems, also the recovery of plant or animal ecosystems; (4) utilizing environmental services and developing marine ecotourism to empower communities around the area; (5) ensuring surveys, studies, research, and activities that produce innovative breakthroughs in waste management; (6) increasing institutional capacity through adding the number of staff, doing education and training, managing human resource placement system, funding, and improving management facilities.

The support given to Wakatobi National Park can be seen from the Spatial Plan of Buton District (before the formation of Wakatobi District) which states that Wakatobi National Park area is classified as a special area to preserve the environment. It means that the existence of Wakatobi National Park has received support from local governments and communities. Unfortunately, the conditions on the area have not fully demonstrated the integration between related parties. The Wakatobi National Park management realized that there are still weaknesses in the adoption process, so it is considered to have not gone through the consultation process at various levels. Also, the space division is not aligned with the designation functions and needs, so the determination of the old zoning causes a lot of conflict in the area.

There are three main principles of the management on Wakatobi National Park area, namely preservation, protection and utiliza tion. Preservation, especially the preservation of protected animal species such as preserving the existence of turtle species. Protection is an effort to manage and protect coral and fish species by continuous monitoring. Then the utilization is the management effort to manage the community wisely so then be able to use the environmental-friendly fishing gear. For more than a decade, Wakatobi National Park office has been trying to socialize to the community the importance of preserving Wakatobi National Park by involving them in monitoring, such as being a forestry police partner. Also, Wakatobi National Park continues to monitor the quantity and quality of resour ces.

These efforts need to be appreciated as an effort for Wakatobi National Park conservation. Another fact was shown that there are still cases of violations committed by irresponsible people. The Wakatobi National Park officials said that the patrol done was not enough to punish the vandalism. They understand the many needs for the community, as well as the lack of personnel to oversee the park, remained unresolved obstacles. For this reason, sustainable management requires collaboration between many parties as human responsibility for nature. It can be done by managing sustainable marine ecotourism based on the local wisdom of the community. The sustainable tourism development based on the community can be carried out in two stages namely, the exploration of the tourism sector and the man agement that focuses on economic benefits for the communities such as supporting and educational development (Purnomo et al., 2020).

The role of the Bajo people is needed to be able to maintain the coastal and marine resources. Collaborating to manage local wisdom with the Bajo Mola community is a way to achieve the continuation of Wakatobi National Park. Sustainable ecotourism can be done with the role of local communities and their understanding of sustainability (Eshun and Tichaawa, 2020). Bajo people were not only used as forest police partners, but the knowledge of Bajo local wisdom can be the basis for planning the management policies later. Bajo people consider that Wakatobi National Park needs to learn about Bajo culture and their local wisdom further in order to be able to maintain sustainability. Then the suspicion and accusation against the Bajo as a marine destroyer can be dropped. Involving the Bajo Mola community was proof that the Bajo people have a great sense of responsibility towards marine conservation.

For more than ten years, the Bajo people felt that the zoning system limited the community to make a living. They also assumed that the Wakatobi National Park had paid less attention to the fulfilment and welfare of the community. Several people claimed that it is uneasy for the Bajo people to be actively involved in the sea due to patrols and others. They also claim that most of them were labelled as naughty, overly consumptive and not considerate of sustainability, and often selfish and not thinking about the future. However, Bajo people were well aware that the sea is a garden, a place to live, and such as a very close relative. They realize the importance of protecting coral reefs. For Bajo people. The reef was one of the marine resources that needs to be maintained over generation

The local wisdom of Bajo Mola community such as the duata sangal, parika and pamali showed that the Bajo people have been guarding the sea for a long time. They even said that they are ready if they were asked to be supervisors of the security. The way to preserve the local wisdom was by asking the Wakatobi National Park to monitor when the fish lay eggs, provide communication between the fishers and the officials by providing handy-talk or other communication tools, ask the policies to ban buying fish from booming or anaesthesia to the collectors or business people, and continue to provide information about the importance of Wakatobi National Park. Besides, the involvement of the local government and traditional leaders is expected to continue to improve socialization so that the Bajo culture about managing marine resources will not be lost over the times.

\section{CONCLUSION}

The results of this study concluded the importance of integrating the local wisdom of the Bajo Mola community in the manageme nt of the Wakatobi National Park area. The local wisdom of the Bajo community such as duata sangal, parika and pamali was as an effort to manage marine ecotourism areas by considering the fulfilment of community needs and welfare without leaving the preservation and sustainability of the Wakatobi National Park. The beauty and resources in Wakatobi National Park are the main assets as the world best marine ecotourism destination.

\section{Aknowlegments}

This work was supported by PNBP research grant of Universitas Negeri Malang 2020.

\section{REFERENCES}

Albrecht, J.N. (2010). Challenges in tourism strategy implementation in peripheral destinations -The case of Stewart Island, New Zealand. Tourism and Hospitality Planning \& Development, 7(2), 91-110. Albrecht, https://doi.org/10.1080/14790531003737102

Artanto, K.Y. (2017). Bapongka, Sistem Budaya Suku Bajo dalam menjaga Kelestarian Sumber Daya Pesisir [In Malay]. Sabda 12(1), 52-69. https://ejournal.undip.ac.id/index.php/sabda/article/view/15253

Bahtiar. (2012). The Local Genius Applied by The Bajo People to Managing Sea Sources. Mudra 27 (2), $178-85$.

Bennett, N.J. (2019). Marine social science for the peopled seas. Coastal Management, 47(2), 244-252. https://doi.org/10.1080/08920753.2019.1564958

Clifton, J., \& Majors, C. (2012). Culture, conservation, and conflict: perspectives on marine protection among the Bajau of S outheast Asia. Society \& Natural Resources, 25(7), 716-725. http://dx.doi.org/10.1080/08941920.2011.618487 
Dirhamsyah. (2016). Setbacks in the development of marine protected areas in Indonesia. Australian Journal of Maritime \& Ocean Affairs, http://dx.doi.org/10.1080/18366503.2016.1187781

Dilwan, A.M., Astina, I.K., \& Bachri, S. (2019). Pariwisata Wakatobi dalam Perspektif Produksi Ruang [Wakatobi tourism in the perspective of spatial production]. Jurnal Pendidikan, Teori, Penelitian, dan Pengembangan, 4(11), 1496-1503. http://journal.um.ac.id/index.php/jptpp/article/view/13017

Dilwan, A.M., \& Astina, I.K. (2019). Community Based Wakatobi Tourism Management Strategies. In 1st International Conference on Social Knowledge Sciences and Education (ICSKSE 2018). Atlantis Press. https://dx.doi.org/10.2991/icskse-18.2019.9

Eshun, G. \& Tichaawa, T.M. (2020). Community Participation, Risk Management and Ecotourism Sustainability Issues in Ghana. GeoJournal of Tourism and Geosites, 28(1), 313-331. https://doi.org/10.30892/gtg.28125-472

Firdaus, F., Shalihin, S., Anggreta, D.K., Yasin, F., \& Tutri, R. (2019). Improving the Benefits of Karamba Into Tourism Activities: An Effort to Reduce the Ecological Impact of Aquaculture in Maninjau Lake, Indonesia. GeoJournal of Tourism and Geosites, 26(3), 726-736. https://doi.org/10.30892/gtg.26304-392

Elliott, G., Bruce, M., Bonnie, W., Abdul, M., \& Susan, W. (2001). Community Participation in Marine Protected Area Management: Wakatobi National Park, Sulawesi, Indonesia. Coastal Management, 29, 4, 295-316, http://dx.doi.org/10.1080/089207501750475118

Khasanah, M., Nurdin, N., Mitcheson, Y.S. D., \& Jompa, J. (2020). Management of the Grouper Export Trade in Indonesia. Reviews in Fisheries Science \& Aquaculture, 28(1), 1-15.https://doi.org/10.1080/23308249.2018.1542420

Kurniawati, E., Sumarmi, \& Aliman, M. (2020). Participation of Green Environmental Group and Ulur-ulur Local Wisdom on Buret Lake Ecotourism Management in Karst Area of Tulungagung, Indonesia. GeoJournal of Tourism and Geosites, 30 (2 supplement), 889-895. https://doi.org/10. 30892/gtg.302spl15-519

Lewin, W.C., Weltersbach, M. S., Ferter, K., Hyder, K., Mugerza, E., Prellezo, R., \& Strehlow, H.V. (2019). Potential environmental impacts of recreational fishing on marine fish stocks and ecosystems. Reviews in Fisheries Science \& Aquaculture, 27(3), 287-330. https://doi.org/10.1080/23308249.2019.1586829

Marfa'i. (2012). Pengantar Etika Lingkungan Dan Kearifan Lokal [Introduction to environmental ethics and local wisdom]. Yogyakarta, Gadjah Mada University Press.

Masita. (2012). Pendidikan Karakter Berbasis Budaya Lokal Pada Masyarakat Muslim. Jurnal Studi Masyarakat Islam, Vol. 15, No. 2, 302-320.

Moleong, L.J. (2016). Metode Penelitian Kualitatif, [Qualitative research methods]. Bandung, PT Remaja Rosdakarya.

Mutia, T., Sumarmi, S., Bachri, S., \& Budijanto, B. (2019). A Study on Bayan Community Perception Towards Awiq-awiq Local Wisdom Based Forest Management. In 1st International Conference on Social Knowledge Sciences and Education (ICSKSE 2018). AtlantisPress. https://dx.doi.org/10.2991 /icskse-18.2019.8

Nasrun. (2016). Partisipasi Masyarakat Dalam Pengelolaan Ekowisata Bahari Di Pulau Kapota Taman Nasional Wakatobi [Community participation management of marine ecotourism on the kapota island of Wakatobi National Park]. Dari. http://etd.repository.ugm.ac.id/home/detail_pencarian/95437

Piartrini, P.S. (2018). The Relationship Among Community Based Tourism Application, Community Attitude, Community Empowerment, and Community Life Satisfaction. E-Journal of Tourism, 5(2), 130-143. https://pdfs.semanticscholar.org/0bf8/b992464da57db66c00ce6ad96e042008869a.pdf

Purnomo, A., Idris, I., \& Kurniawan, B. (2020). Understanding Local Community in Managing Sustainable Tourism at Baluran National Park - Indonesia GeoJournal of Tourism and Geosites, 29(2), 508-520. https://doi.org/10.30892/gtg.29210-485

Sartini. (2004). Menggali kearifan lokal nusantara sebuah kajian filsafatih [Explore the local wisdom of the archipelago as philosophical study]. J. Filsafat UGM 37. 112.

Sopari, H., Oka, N.P., \& Salman, D. (2014). Model Kolaborasi Perencanaan Antara Balai Taman Nasional Wakatobi dan Pemerintah Kabupaten Wakatobi dalam Pengelolaan Sumber Daya Alam Hayati Secara Lestari. J Sains \& Teknologi, 14(2), 189-198. http://pasca.unhas.ac.id/jurnal/files/ 827db9e2d02070326ee7240b9c2289b3.pdf

Sumarmi. (2018). The Local Genius of Tengger People in Conserving Forest and Increasing Economic Benefits Using Agroforestry System. IOP Conference Series, Earth and Environmental Science, 145(1), 012135. https://doi.org/10.1088/1755-1315/145/1/012135

Sumarmi., Bachri, S., \& Tanjung, A. (2019). Madurese Fishermen's Adaptation to Marine Environment-Based Approach in Fisheries Resources Management by Empowering the Local Wisdom of "Onjem". In 1st International Conference on Social Knowledge Sciences and Education (ICSKSE 2018). Atlantis Press. https://Doi.Org/10.2991/Icskse-18.2019.21

Sumarmi., Bachri S., Tanjung A., \& Mutia, T. (2019). A Study on The Local Wisdom of The Bali Aga Community Metruna Nyoman in the Indigenous Forest as An Effort to Build Character of Caring for the Environment. Ecology, Environment and Conservation. Vol 25, Issue 4 2019; Page No. (1638-1643)

Sumarmi, Kurniawati, E., \& Aliman, M. (2020). Community-based Tourism (CBT) to Establish Blue Economy and Improve Public Welfare for Fishing Tourism Development in Klatak Beach, Tulungagung, Indonesia. GeoJournal of Tourism and Geosites, 31(3), 979-986. https://doi.org/10.30892/gtg.31307-530.

Sumarmi., Bachri. S., Irawan. L.Y., Kurniawati E. (2020). Cultural Ecology of Osing in Development of Kemiren Tourist Village as International Tourist Attraction. IOP Conf. Series, Earth and Environmental Science, 485 (2020) 012017 IOP Publishing. https://iopscience.iop.org/article/10.1088/1755$1315 / 485 / 1 / 012017$

Suprayogo, I. (2013). Pengembangan Pendidikan Karakter [Development of Character Education], Malang, UIN-MALIKI PRESS.

Turak, E. (2003). Coral reef surveys during TNC SEACMPA RAP of Wakatobi National Park, Southeast Sulawesi, Indonesia. Bali, The Nature Conservancy.

Wagiran. (2012). Pengembangan Karakter Berbasis Kearifan Lokal Hamemayu Hayuning Bawana (Identifikasi Nilai-Nilai Karakter Berbasis Budaya) [Character development based on local wisdom of Hamemayu Hayuning Bawana (identification of culture-based character values]. Jurnal Pendidikan Karakter, No.3.

Wani, K.A., \& Ariana. L. (2018). Impact of climate change on indigenous people and adaptive capacity of bajo tribe, Indonesia. Environmental Claims Journal, 30(4), 302-313. https://doi.org/10.1080/10406026.2018.1504380

Wahyuni, D.E. \& Hasnah, S.A. (2016). Pendidikan Karakter Berbasis Kearifan Lokal Pembentuk Karakter Bangsa [Character education based on local wisdom formed the national characters]. Seminar Nasional Pendidikan "Pengembangan Pendidikan Karakter Bangsa Berbasis Kearifan Lokal dalam Era MEA" ISSN, 2549-3728, Vol.1, 19-24. Universitas Negeri Jember. https://doi.org/10.1080/23308249.2019.1586829

*** BMKG (2020). Prakiraan Cuaca Sulawesi Tenggara-Indonesia [Weather forecast of Southeast Sulawesi Indonesia]. BMKG. BMKG Badan

Meteorologi, Klimatologi, dan Geofisika (Meteorology Climatology and Geophysics Council). https://www.bmkg.go.id/cuaca/prakiraan-cuaca-indonesia.bmkg?Prov=30\&NamaProv=Sulawesi Tenggara

*** BPS (2019). Wakatobi dalam angka 2019. Badan Pusat Statistik Kabupaten Wakatobi [Central Bureau of Statistics in Wakatobi] https://wakatobikab.bps.go.id/publication.html

*** MENHUT (1996). Surat Keputusan (Decree) No. 393/Kpts-VI/1996. Penunjukan Taman Nasional Wakatobi [Appointment of Wakatobi National Park]. Kementerian Kehutanan Republik Indonesia.

*** MENHUT (1997). Keputusan Direktur Jenderal Perlindungan Hutan dan Pelestarian Alam [Decree of the Director General of Forest Protection and Nature Conservation]. No 198/Kpts/DJ-VI/1997. Kementerian Kehutanan Republik Indonesia.

*** MENHUT (2002). Surat Keputusan (Decree) No 7651/Kpts-II/2002. Penetapan Taman Nasional Wakatobi [Establishment of Wakatobi National Park]. Kementerian Kehutanan Republik Indonesia.

** Rencana Pengelolaan Jangka Panjang Balai (RPJP TNW) [Long-term management plan of Wakatobi National Park office], $2018-2027$.

*** UNESCO (2012). Ecological Sciences for Sustainable Development. United Nations Educational, Scientific and Cultural Organization. http://www.unesco.org/new/en/naturalsciences/environment/ecologicalsciences/biosphere-reserves/asia-and-the-pacific/indonesia/wakatobi/ 